\title{
Management Allied to Industry: Development of Metallic Packaging "Rack" Applied to the Automotive Sector
}

\author{
Adriano José Sorbile de Souza ${ }^{1}$, Érik Leonel Luciano ${ }^{1,2}$, Igor Alexandre Fioravante ${ }^{1}$, Jorge Luiz Rosa ${ }^{3,4}$, Rosenil \\ Honorato de Melo ${ }^{1,5}$ \& Rosinei Batista Ribeiro ${ }^{1,2,4,6}$ \\ ${ }^{1}$ Faculty of Technology - FATEC - Cruzeiro Unit, São Paulo State, SP, Brazil \\ ${ }^{2}$ State Center for Technological Education Paula Souza - CEETEPS - Postgraduate, Extension and Research Unit - \\ São Paulo, Brazil \\ ${ }^{3}$ State Center for Technological Education Paula Souza - CEETEPS, Brazil \\ ${ }^{4}$ Teresa D`Ávila University Center - UNIFATEA - Lorena, Lorena School of Engineering, EEL - USP, Lorena, SP, \\ Brazil \\ ${ }^{5}$ ETEC Padre Carlos Leôncio da Silva, Lorena Unit, SP, Brazil \\ ${ }^{6}$ Technological Institute of Aeronautics - ITA, Institute of Advanced Studies - IEAv, Department of Aerospace \\ Science and Technology - DCTA - São José dos Campos, SP, Brazil \\ Correspondence: Érik Leonel Luciano, Faculty of Technology - FATEC - Cruzeiro Unit, State Center for \\ Technological Education Paula Souza - CEETEPS - Postgraduate, Extension and Research Unit - São Paulo, Brazil.
}

Received: May 18, 2021

doi:10.5430/ijba.v13n2p1
Accepted: June 28, 2021

Online Published: February 27, 2022

URL: https://doi.org/10.5430/ijba.v13n2p1

\begin{abstract}
This work aimed to design industrial packaging, type "metallic racks" for automotive components and assemblies, which contribute to the effective reduction of storage and transportation costs, potentiating the reduction of times and movements in environmental processes and liabilities. As an application, bibliographic, exploratory and product development research was used, which consisted of diagnosing the problematic situation for the development of the "Rack": standardized packaging / occupancy rate, handling / times and movements, Lean Manufacturing, ergonomic aspects, environmental processes and analysis of the material / construction process. As a result, it was found that the use of the Metallic "Rack" impacted in the company's money savings impacted an express economy for the company, with a reduction of $82 \%$ in the storage area, $89 \%$ in the times and movements involved in the packaging activity, among others. As an academic and scientific contribution, this work helps to expand studies in the most diverse aspects that affect the production process, logistics, racking design, ergonomic analysis and a product value chain.
\end{abstract}

Keywords: design and material selection, metal "racks", supply chain management, lean, production and operations management

\section{Introduction}

The series production systems, coming from the 2 nd Industrial Revolution, can be considered as an initial milestone in the concept and process of packaging evolution. The increase in complexity of processes and consequently in movement of products, made it necessary to develop and use packaging with the most varied types, shapes and materials. In the course of this evolution, packaging began to be used not only to pack the final product, but also during the stages and processes of manufacturing, handling and transporting raw materials, components, semi-finished products and final products (BHATTARAI, 2019 and CASTRO, 2005).

Santos (2018), considers the import substitution process, which occurred after the Second World War, as a significant boost to the country's industrialization and consequently to a greater demand for packaging of the most varied types and materials throughout of the process. This growth in consumption also generates an increase in demand, in which the productive sectors start to expand their production, using greater quantities of raw materials and components of different types and shapes, making it necessary to manufacture and, consequently, a greater use of packaging.

Then, the following sequence of activities is observed in production process:

- In manufacturing, with receipt of inputs consisting of raw materials and components in general, there is indirectly 
the receipt and use of packaging and also indirectly a liability for packaging waste such as wood, cardboard, plastics, among others that require treatment and a proper disposition.

- In transportation, factors such as the need to protect products, whether finished or in a semi-finished process, also make it essential to use packaging as a primary function of product integrity, protecting it from potential damage, such as climatic, bacteriological and traffic accidents and handling.

The packaging is no longer just the function of easy distribution when it was used. It remains today, but due to the discovery that consumer packaging is the most significant representative that the company has for the customer, a few more were added:

- Facilitate storage - packaging must be designed to reduce costs, the shape and size of these are changed to palletize volumes for transportation. The less handling, the lower distribution costs;

- Protect and preserve the product - against any demand or movement dynamics. Packaging must serve to protect the product at the point of sale, that is, at the dealer;

- Positioning the product - knowing how to position the product on shelves is essential;

- Facilitate the use of product - Packaging must be always appropriate to the type of use of product.

- Marketing - this function is attractive to the consumer by means of an adequate design (Motion) and the combination of colors, patterns, formats, styles and illustrations.

The present project aimed to develop a metallic packaging, "Rack" type, with the purpose of improving the industrial, internal and external logistics system of the company, by means of technical design solutions (in 2 and 3D formats), in order to reduce the costs with handling and transportation, aiming at increase the safety and quality of the process that contributed to the optimization of packaging occupation in which they eliminated the residues generated by customer, making the logistics system more dynamic, which includes: the supply of materials and components, the movement and control of products and the support to the sales effort in the final phase of the production chain, until the placement of the finished product to the customer.

By means of direct observations in productive and logistical process of the item in question, it was noted that employees perform several movements to pack a single piece inside the packaging used for transportation. Due to the fact, the new design of the "Rack" packaging, in addition to increasing the occupancy rate of the packaging, will bring the employee a reduction in the times and movements spent in handling and storage used in this operation, collaborating with the efficiency of ergonomics, easing the damage to workers' health and significantly increasing productivity gains.

Among the gaps observed in relation to the production process, packaging and logistics, results were obtained from demerits, resulting from the compromised quality of product upon reaching its final destination (customer), resulting in: product rejection, rework and disposal, causing financial losses and descent in the supply performance index.

The development of specific packaging using the product design concept sought to design a "Rack" that was the determining factor to achieve product quality assurance and gains for both parties.

The making of a new "Rack" type packaging was developed to meet the demand for parts manufactured by the partner company and all aspects mentioned can be guaranteed by means of the new project elaborated with the primary aid of concept in design, resulting in a packaging "Rack" properly suited for this purpose.

As a contribution, the article expands the study of several aspects that affect the production process, logistics, design of rack, ergonomics analysis and the product value chain. The project also focuses on contributing to new studies in the area of development and creation of product design, where it was possible to elaborate a whole diagram of the verticalization of a rack, which with its construction, through tests, was identified that in compared to other conventional racks, which allows the transport of three times more modules, as well as costs.

\section{Theoretical Foundation}

\subsection{Lean Manufacturing}

Japanese and world-class companies worked on the concept of Just-In-Time manufacturing, which was developed by Taiichi Ohno of Toyota ${ }^{\circledR}$ whose premise is to meet consumer demand (customer) with the minimum delay in their processes and products. These practices ensure a significant increase in product quality and employee involvement in all spheres of knowledge and competence (BHASIN and BURCHER, 2006), (BHAMU and SINGH SANGWAN, 2014). 
Its adoption is based on five principles (a) identifying / defining value, (b) mapping the value flow, (c) creating flow, (d) establishing a pull system and (e) striving for perfection. The integration of these principles in sequence allows value flow managers to identify inefficiencies and develop better flows in production processes, to increase value for their customers and to create a culture of excellence (ÅHLSTRÖM, 1998), (ÅHLSTRÖM AND KARLSSON, 2000).

Recently, it is highlighted that these principles are operationalized differently by companies, leading to a disconnect between theory and practice (NARAYANAMURTHY et al., 2018), and the maturation of normative procedures in lean processes has significantly advanced in philosophy than in real theory and the mechanisms that govern Lean practices that require greater organizational maturity with consequences in controlling inventory management and reducing variability (BROWNING AND HEATH, 2009), (HÜTTMEIR et al., 2009).

Lean Manufacturing is not just a modern term with tangible values in all organizational sectors, it is a philosophy (BHASIN AND BURCHER, 2006), that allows industries to do better (high performance), using the principles of continuous improvement and changes in your organizational culture. In addition, Lean Manufacturing supports the reduction of waste, causing an increase in quality and speed, responding to customer demand, as well as products, processes and strategic information (BHAMU AND SINGH SANGWAN, 2014).

The universality of Lean is such that its implications can be seen clearly and objectively in best practices in business and operational performance in the organization (NAWANIR et al., 2013). The main vector in manufacturing, like Just in time, has a significant impact on operational performance (RAHMAN et al., 2010).

The implementation of lean manufacturing principles significantly reduces production time (RAHANI AND AL-ASHRAF, 2012), regardless of the size of the organization (MATT AND RAUCH, 2013), and that to achieve long-term strategic goals and objectives, it is necessary to use of lean manufacturing techniques to reduce waste and provides detailed guidance for managing process improvement (SUNDAR et al., 2014).

However, it was noticed that the attitude of the workers and the complete understanding of the concepts are essential for the successful implementation of the lean system effectively (NORDIN et al., 2010), and that the Just in time and Total Quality Management it is necessary for greater employee involvement, higher levels of productivity and higher quality standards.

In this path to be followed, the description and analysis of the value chain follows the methodology Value Stream Mapping (VSM) or Value Chain Mapping (VCM), which can be defined as a vector and its points in a production line of a product, or service from the consumer to the supplier, and moderately at each point in the supply chain management and in its flow of material and information (ROTHER AND SHOOK, 2003).

However, the Value Chain Mapping, seeks to simply understand its flow, now materials, services and information to identify and mitigate waste, finding the point of accuracy in the value flow, harmonization and unification of communications throughout manufacturing processes, the post-process thinking strategy, the flow architecture in full operation in order to understand the entire supply chain (LIKER, 2004), (MONDEN, 2015), (WOMACK AND JONES, 1998), (WOMACK, et. al. 2004).

In their article, (FURMAN J., MALYSA T., 2021), using the concept of Lean Manufacturing, in a practical case, demonstrate that reducing waste and improving the organization of production contributes to reducing costs and effectively implementing the tasks of production.

It is noteworthy that companies have also used the Lean concept with a focus on increasing their competitive advantage in the increasingly competitive market. However, according to (VALLEJO et al., 2020), due to the incorrect use of this concept in practice, it results in a high rate of implementation failure. There is a need for a structured and standardized framework to describe how a Lean initiative should be implemented and sustained over time. The authors (VALLEJO, et al., 2020) have developed a practical and strategic roadmap for a Scottish small and medium packaging company (SME), which can be used by other similar SMEs.

\subsection{History, Concepts and Functions of Packaging}

The packaging has its genesis in the beginnings of human civilization, because it derives from the basic need of the human being to feed himself and to look for ways to store and preserve his food for longer.

Negrão (2008), claims that the evolution of packaging is also mixed with the history of technological development. As humanity evolves, it discovers new materials, develops new needs and also expands the range of products it makes use of. As a consequence, the number of products to be packaged increases and the diversity of materials used in these packages increases proportionally.

For other authors, packaging has historically appeared with the purpose of containing and protecting the product as it 
passes through the distribution channels. Most of the products were transported in large packages and sold in bulk and, in many cases, repackaged manually by retailers at the time of sale.

The advent of self-service reinforced the importance of packaging and started to demand it as an element of attraction for the consumer to the product, making it decisive with regard to the performance of mass consumption products (ROCHA, 2008).

This change could be experienced in Brazil in the second half of the 1950s, a decade in which the market, until then dominated by bazaars, haberdasheries, greengrocers and emporiums, witnessed the emergence of supermarkets, the trigger for a revolution in the world of packaging.

For Moura (1997), and Santos Junior (2019), creation and improvement of packaging started at the origin of humanity. In the beginning, hands were used as transport, but in them, water could not be transported far away, nor was it possible to store it. Animal skulls, hollow horns and large shells began to perform these important tasks.

Consumer goods packaging is a fundamental element for modern life, as it plays an important role in economy and in behavior of society. The main function of packaging is, and always will be, to protect and enable the efficient transport and storage of a product within the logistics chain.

Calver (2009), and Farias (2019), describe that the function of packaging was related to its usefulness, especially when it helped in the effective distribution of product. Despite the fact that nowadays products and packaging are more sophisticated, the basic functions are still very important in their form and function, since they must protect the product until the final consumer.

The Brazilian Packaging Association (ABRE, in Portuguese), defines packaging as a container or wrapper that stores products temporarily, individually or by grouping units, whose main function is to protect them and extend their shelf life, enabling their distribution, identification and consumption.

The importance of packaging is observed in view of the several variations in concept and their relationships in which the vision of each area of organization, shows that, despite the main objective of protecting the product, the packaging has numerous business features (MANTOVANI, 2014).

Recently studies have been developed with focuses on the behaviour of steel storage selective pallet racks, and their typical configuration. The main structural frame of storage pallet racks is composed of cold-formed thin-walled steel members, such as uprights, pallet beams and bracings. Pallet beams are welded to beam-end-connectors, and upright members have arrays of holes along the length, which allow pallet beams to be connected at variable heights and brace members to be bolted to form upright connections and column bases (CARDOSO, 2016; BALDASSINO, 2000; ABDEL-JABER, 2006; BERNUZZI, 2016; LIUSI DAI, 2018, UMAR, 2019).

\section{Methodology}

\subsection{Proposal of Technical Intervention}

For the development of the work, the methodology had eight stages of development, namely: Problem Identification; Standardized Packaging/Occupancy Rate; Handling/Times and Movements; Analysis of Material/Manufacturing Process; Ergonomic Aspects; Environmental Liabilities; Standardized Packaging/Occupancy Rate and Handling/Times and Movements, Figure 1:Include in these subsections the information essential to comprehend and replicate the study. Insufficient detail leaves the reader with questions; too much detail burdens the reader with irrelevant information. Consider using appendices and/or a supplemental website for more detailed information.

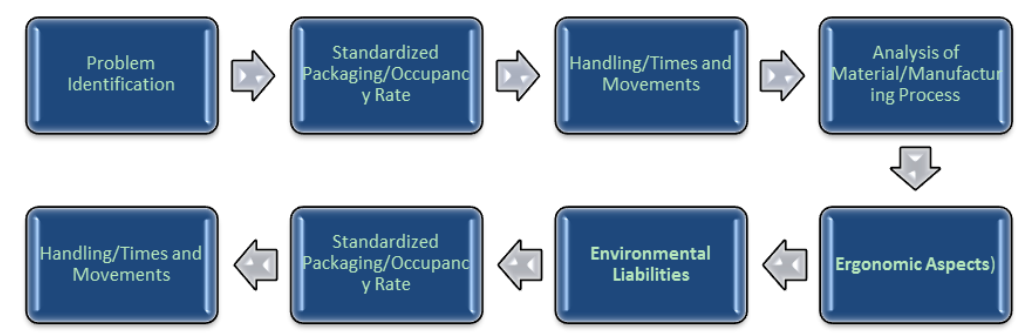

Figure 1. Stages of activities developed for the feasibility of time, costs and the project's preview technique Source: The authors. 


\subsection{Problem Identification}

The applied research focused on technical intervention in direct observation of productive and logistical activities in the company. Techniques were applied in the sectors: procedures and materials used for the transportation and handling of processed and finished products.

Manufacturing process flow of set 22B.701.031 (Figure 3), starts after receipt and release of raw material by quality sector, after being approved, this raw material is sent to the guillotine sector, where the plates are transformed into blanks, specifically serving each component of this set; after this process, blanks are directed to the stamping in which they will be mechanically shaped by hydraulic and eccentric presses, in order to meet the geometric shapes requested in design, thus forming the components. Then all items are sent in wire mesh baskets to the welded sector, after the MIG/MAG (Metal Inert Gas/Metal Active Gas) welding process, these individual components result in the final set, which will have the following operation as KTL E-coat paint (Kathodifsche Tauch Lackierung), so that it is then packaged and sent to the shipping sector.

The problems encountered during the on-site study are directly linked to the current packaging concepts used by the company during the internal and external production and logistical processes that meet internal technical documentation, where, internally, it makes use of a wire basket for the transport and overflow of components (Figure 1), it occurs that their corrosion when in contact with the packaging and for the final shipment, a large amount of primary and secondary packaging is used (Figure 2), in addition to a low rate of occupation on the pallet and the transported cargo.

These packages are unsuitable for the process/transport, causing internal disturbances to production, logistical problems and compromised product quality assurance, often causing damage, resulting in rework and demerits, contributing to customer dissatisfaction and countless financial losses to the partner company.

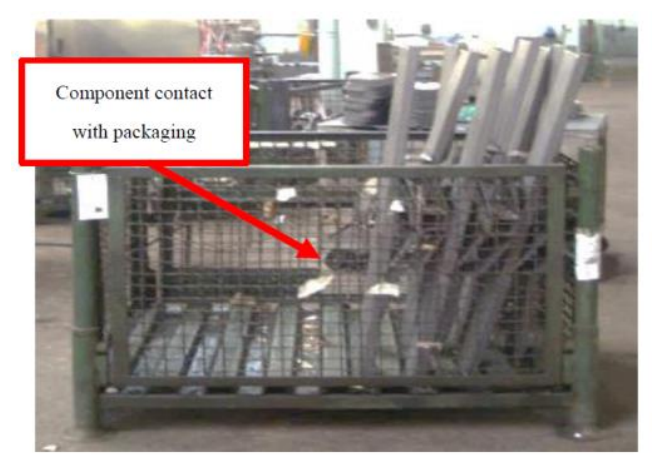

Figure 2. Wire basket used during the internal movement of components

Source: The authors.

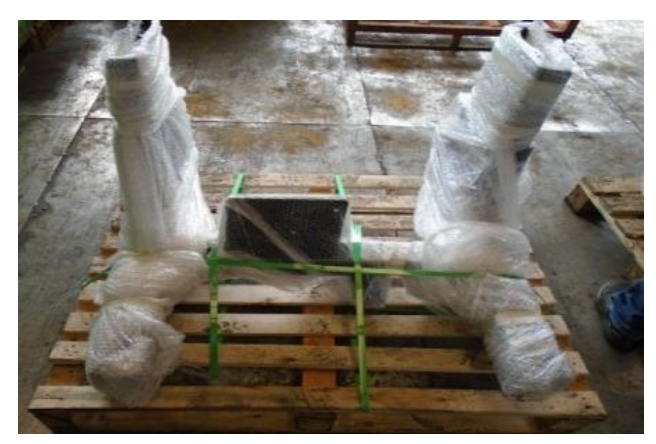

Figure 3. Representation of the packaging used for final shipping to the partner company

Source: The authors. 


\subsection{Standardized Packaging/Occupancy Rate}

Companies increase the cost reduction, however, few understand that an inadequate projected packaging impacts on the price of final product and that the development of specific packaging brings great reductions in transportation costs.

The company, object of this study, makes use of standardized wooden pallet type packaging with dimensions of 1000 x $1000 \mathrm{~mm}$ (Figure 4), using them for a wide variety of items produced, however this standardization brings serious logistical and movement.

It was observed that the adoption of standardization of packaging by the company causes an excessive number of movements for employees, in which the ergonomic aspects are not fully met.

Due to the specific characteristics of the joint product 22B.701.031, with regard to geometry, dimensions and shape, it was found that there is a significantly useful area within these packages that are not occupied, which contributes to a low occupancy rate, since in each of these packages, only one set is sent to the final customer, which causes a significant increase in the final freight cost.

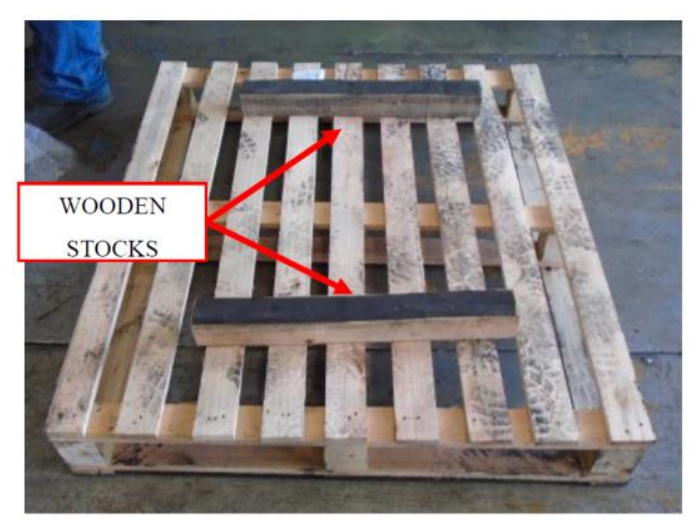

Figure 4. Representation of the pallet and wooden blocks used in the current packaging concept

Source: The authors.

\subsection{Handling/Times and Movements}

The study of methods and times, also known by the terms Method Engineering, Work Project or Work Study, is defined according to Rangel et al. (2012), apud Barnes (1990), as a systematic study of work systems with the objective of making a given operation efficient and standardized.

The development and standardization of a method aims to improve the operation, determining the time spent for training the worker. Specifically, this study aims to rationalize the working method, so that the most efficient use of productive resources occurs, notably the use of labor.

By means of analysis of manufacturing and shipping process of item 22B.701.031, numerous movements made by the operators were identified, which are necessary due to the current packaging concepts used by the company, in addition to the excessive movement, there is a great movement among operations and these become detailed, due to the use of additional materials such as: wooden blocks, strech plastics, adhesive tape and nylon strap.

Therefore, employees perform several movements to position, align and fix the final set in the current packaging, in order to meet the quality standards required by the customer during transport to his final destination.

\subsection{Ergonomic Aspects}

The approach to ergonomic aspects, in the most varied contexts, is always related to interaction between man and system, in turn, almost always referring to the concept of work. Thus, the practical application of ergonomics is justified when it intervenes at the interface that intermediates man and his task.

It was possible to observe that there is a concern on the part of the company, regarding the ergonomic aspects, but there is not a full interaction between man and system. This is due to the countless inadequate movements depending 
on the type of packaging currently used, causing a great increase in ergonomic risk, characterized by: inadequate postures, physical effort, handling loads, repetitive movements and monotonous activities.

In this context, reference was made to the analysis of the real situation in which the company's employees are exposed in the packaging activity of item 22B.701.031.

According to the Ministry of Labor and Employment of Brazil (2018), the working conditions include aspects related to the lifting, transportation and unloading of materials, in addition to the handling and operation of the equipments. Analyzing the workplace during the activity, observing the posture, the movements performed by the employee, as well as the physical demands and requests, are basic and fundamental actions during a project to adapt and meet the requirements of the Regulatory Standard (NR17).

Through the application of the RULA method, an analysis was sought from the study of the human-machine-environment interface; observing the interactions that occur during the performance of this activity. After this ergonomic approach, the development of this project was carried out, adapting and correcting the work activity and, consequently, the job position, reducing the biomechanical requirements and potential occupational diseases, providing to the operator a correct posture during the packaging process. The workplace started to be welcoming with the employee as if it were a fully adapted garment, so he can do his job with comfort, efficiency and safety.

Silva (2018), the RULA is an observational method of jobs whose objective was the integrated classification of the risk of Musculoskeletal Injuries of the Upper Limb in the Workplace, particularly in terms of posture. It does not need sophisticated equipment, it allows to obtain a quick assessment of positions taken by the worker; the forces exerted, the repetition and the external loads felt by the organism. Photographic records of the worker performing the activities in the packaging process for component 22B.701.031 (Figure 18) were used as a work tool and the RULA method (Rapid Upper Limb Assessment) was applied in the analysis of postures and efforts. From there, action levels were obtained, whether acceptable or not, in the postures most frequently in their workday.

Dimate et al (2017), and Namwongsa (2018), RULA method uses postural diagrams and scoring tables that after applying the method and evaluating the different elements and the result of the application is described by levels of action.

By means of RULA, based on an assessment of the upper and lower limbs, it was possible to verify that the current activities do not meet the requirements and recommended ergonomic aspects.

\subsection{Environmental Liabilities}

During the entire product manufacturing process, as well as the packaging process for final shipping to the customer, it is necessary to use primary (Figure 5) and secondary (Figure 6) packaging, such as: wooden pallets and wedges, plastic, adhesive tape and nylon straps for conditioning and fixing the set, to guarantee the packaged and non-moving product.

The packaging used is intended to protect the assembly during its internal movement and all logistics until the final destination, ensuring and meeting the quality standards specified by the assemblers. However, costs of purchasing these materials and their disposal are the responsibility of the partner company.

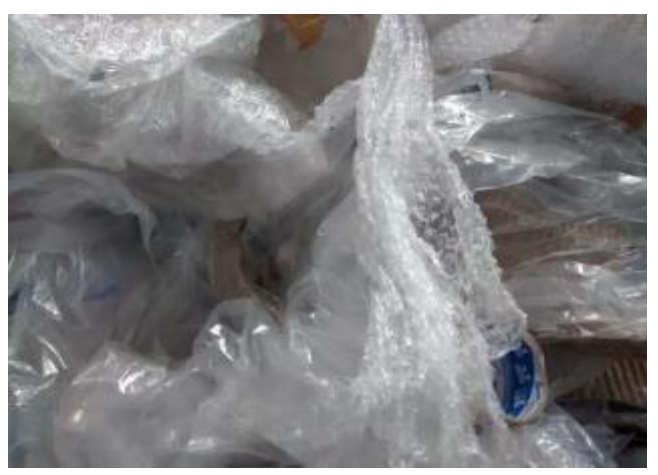

Figure 5. Representation of the primary packaging used in the packaging process of item 22B.701.031

Source: The authors. 


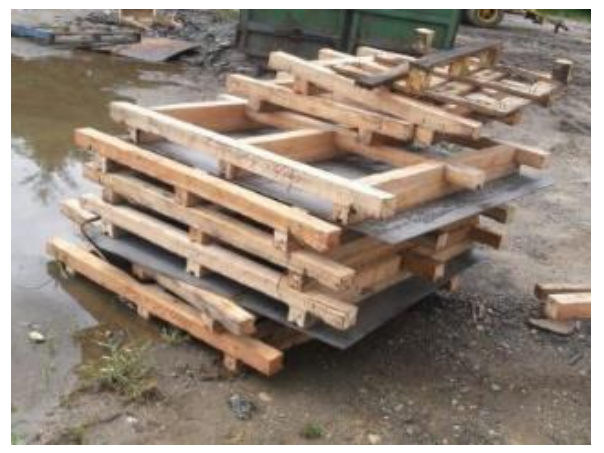

Figure 6. Representation of secondary packaging used in the packaging process of item 22B.701.031

Source: The authors.

\subsection{Analysis of Material/Manufacturing Process}

The wire metal racks used by the company during the production process, are made of SAE 1020 carbon steel and have their elements fixed by means of a MIG/MAG welding process, without any type of surface treatment (painting).

This process of joining different materials, together with the exposure of natural phenomena such as sun, rain and dust, contributes to the corrosion of packaging (Figure 7), which is totally harmful to the process. Galvanic corrosion is evident, which induces non-conformity in product storage; this translates into contact with the packaging during the transfer among operations. Occurrence is noted by the lack of surface protection and constant contact between the difference of the electrochemical pairs (SAE 1020 and Advanced Steels types Dual Phase of the chassis and automotive components).

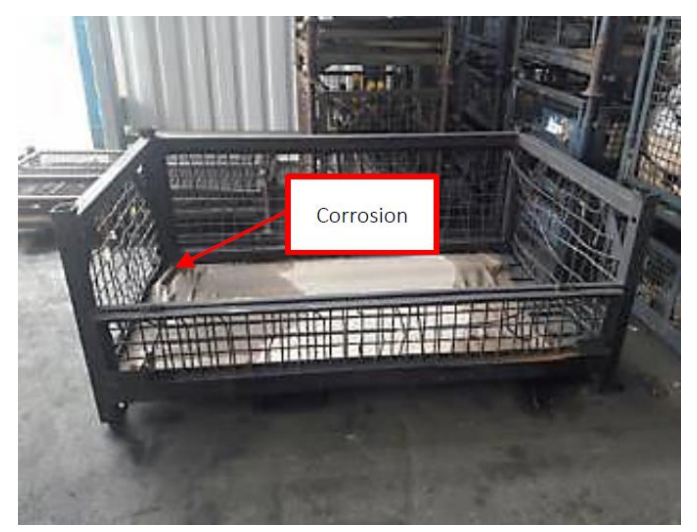

Figure 7. Wired metallic rack used during the manufacturing process of item 22B.701.031 that presents corrosion in its structure

Source: The authors.

\section{Results and Discussion}

\subsection{Technical Detailing of Components}

The technical details of the components of the set (Figures 8, 9, 10 and 11) were carried out at the Materials, Textures and Modeling Laboratory "Prof. Wilson Kindlein Júnior" at the Teresa D'Ávila University Center - UNIFATEA to carry out dimensional analysis using the three-dimensional headlight arm, also calipers and micrometers.

The aime of the methodological step was to characterize dimensions and the mass of the pieces to be packed, in order to define a better position, fixation and possibility of stacking the packages, types "Metallic Racks". 


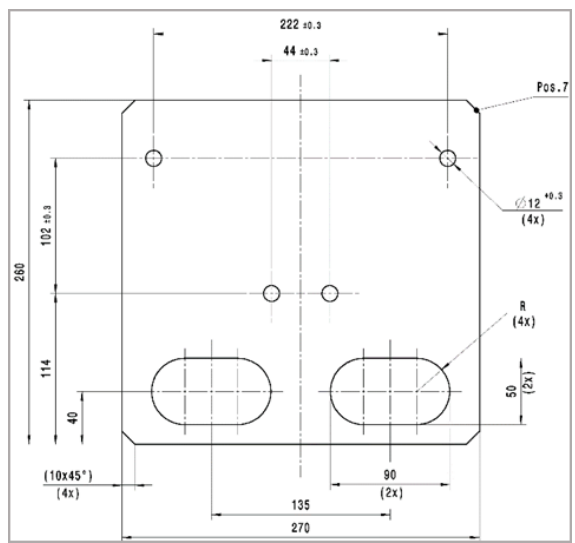

Figure 8. Technical drawing 01 in projection of the set 22B.701.031: Support plate and fixation of components in the intermediate beam

Source: The authors.

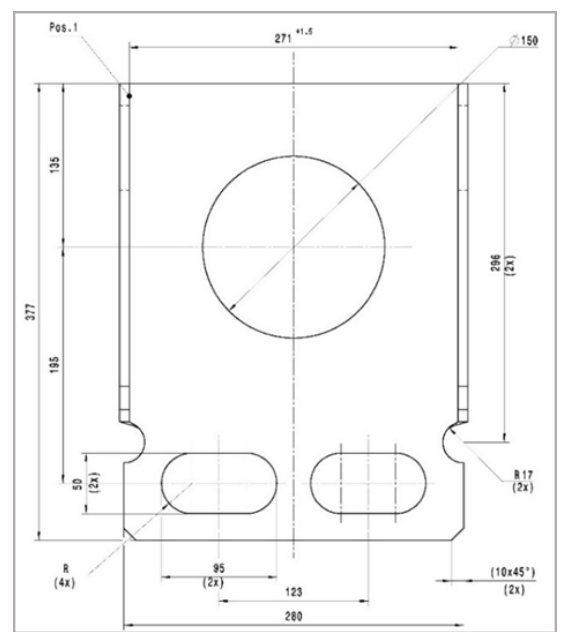

Figure 9. Technical drawing 02 in projection of the 22B.701.031 set: Support bracket (LD) Right side and (LE) (left side) of the LD and LE Chassis fixation tower

Source: The authors.

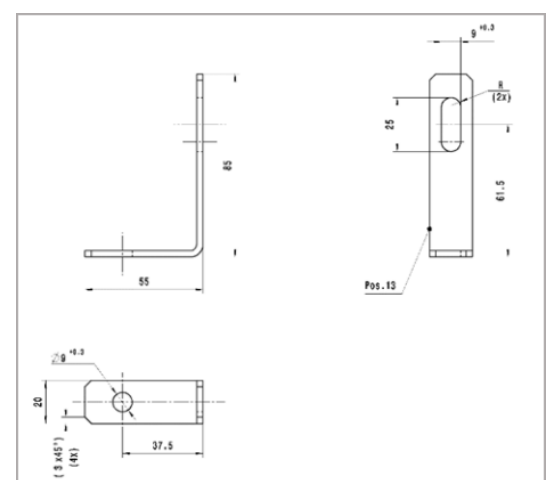

Figure 10. Technical drawing 03 in projection of the 22B.701.031 set: Angle in "L" fixing Plug connector of the harness

Source: The authors. 


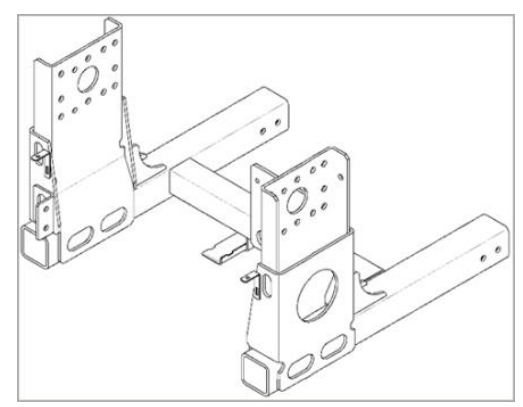

Figure 11. Technical drawing 04 in perspective of the whole of the Central Frame 22B.701.031. Model TGX MAN 312 / M 3000

Source: The authors.

\subsection{Prototype Development - 3D Creation and Modeling of the Set}

For the diagramming of the rack prototype, the software called Inventor ${ }^{\circledR}$ from the AutoDesk ${ }^{\circledR}$ company was chosen, as it has powerful tools for direct editing, freedom modeling and parametric modeling, allowing professionals to validate the fit, shape and function of the finished product before being built.

The creative process and 3D modeling (Figures 12,13,14 and 15) are the components that were developed in the materials, textures and modeling laboratory using specialized and dedicated software for elaboration of designs and geometric models in which, subsequently, the assembly of the set was carried out, taking into account functional and feasibility aspects.

After the completion of several creative processes, a goal was defined and defined as dimensions, mass and fixation system of the set, using the rational way or the physical space available in the Metallic/Piece "Rack" relationship, with a proposed use for the use of packaging, in addition to reducing the costs of the process, transportation and replacement of environmental liabilities.

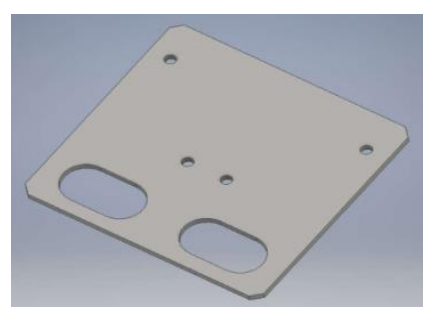

Figure 12. 3D solid modeling of component 01, Set 22B.701.031: Support plate and fixation of components on the intermediate beam

Source: The authors.

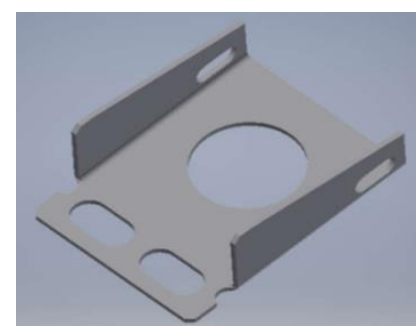

Figure 13. Solid 3D modeling of component 02, Set 22B.701.031: Support bracket (LD) Right side and (LE) (left side) of the transverse fixation tower of the LD and LE Chassis

Source: The authors. 


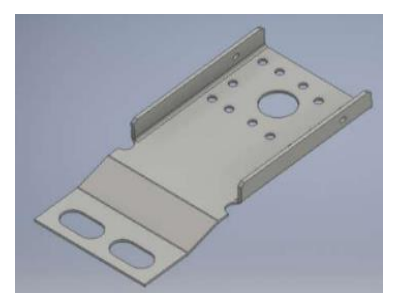

Figure 14. Solid 3D modeling of component 03, Set 22B.701.031: Transverse fixation tower on the LD and LE chassis

Source: The authors.

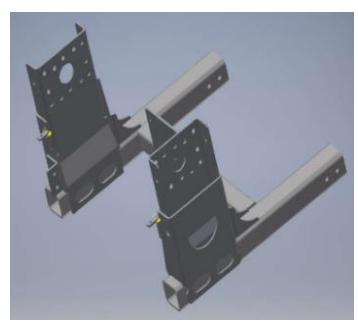

Figure 15. Solid 3D modeling, Central Frame Assembly 22B.701.031, Model TGX MAN 312 / M 3000

Source: The authors.

After making the drawings in the Inventor ${ }^{\circledR}$ software, an analysis of similars and problematization of the product design was carried out, in which the development of a design that met the geometric aspects and the specific physical characteristics of the set was sought.

Photographic records of the worker performing the activities in the packaging process for component 22B.701.031 (Figure 16) were used as a work tool and the RULA method (Rapid Upper Limb Assessment) was applied in the analysis of postures and efforts. From there, action levels were obtained, whether acceptable or not, in the postures most frequently in their workday. The RULA is an observational method of jobs whose objective was the integrated classification of the risk of Musculoskeletal Injuries of the Upper Limb in the Workplace, particularly in terms of posture. It does not need sophisticated equipment, it allows to obtain a quick assessment of positions taken by the worker; the forces exerted, the repetition and the external loads felt by the organism.

RULA method uses postural diagrams and scoring tables that after applying the method and evaluating the different elements and the result of the application is described by levels of action.

By means of RULA, based on an assessment of the upper and lower limbs, it was possible to verify that the current activities do not meet the requirements and recommended ergonomic aspects.

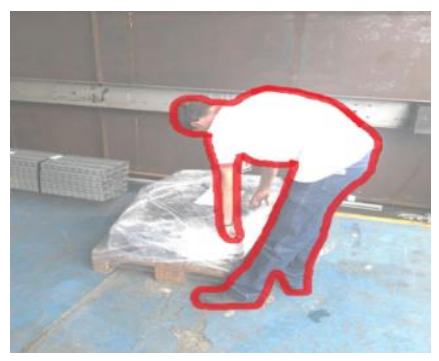

Figure 16. Image of the employee and his movements during the packaging activity of component 22B.701.031 Source: The authors. 
In view of the verification of the results obtained b means of the study, it was possible to state that: with the design of the Metallic "Rack" packaging, it was possible to reduce approximately $82 \%$ in the area used for storage in the company's shipping sector, as the the proposed packaging design offers the possibility of packing three sets in each package, in addition, it allows the stacking of up to three "Racks" (Figure 17), resulting in the verticalized stock with a capacity of 9 pieces, while the wooden pallets currently used do not allow stacking and coupling of the sets in the same package (Figure 18).

There was a significant reduction in the number of sequences in the activity of packing the 22B.701.031 set, which is now performed with greater efficiency and decreased $89 \%$ with the use of the Metallic "Rack" in movement and activity time.

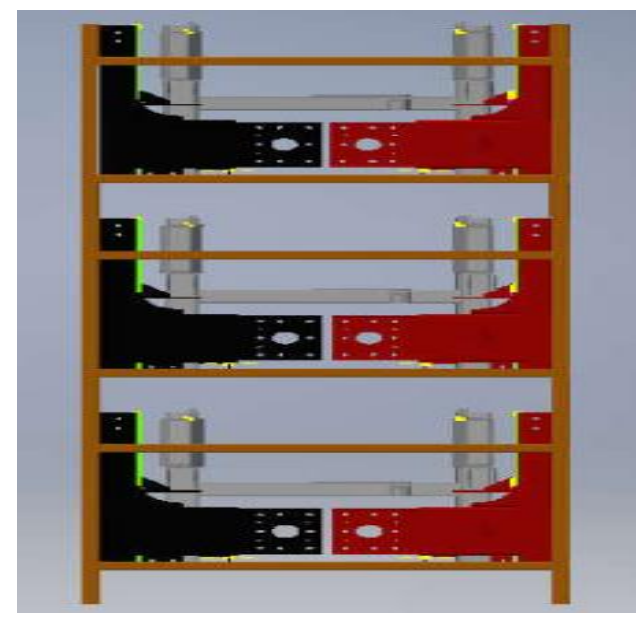

Figure 17. Demonstration of the verticalized stock of "Racks" with a stacking capacity of three units

Source: The authors.

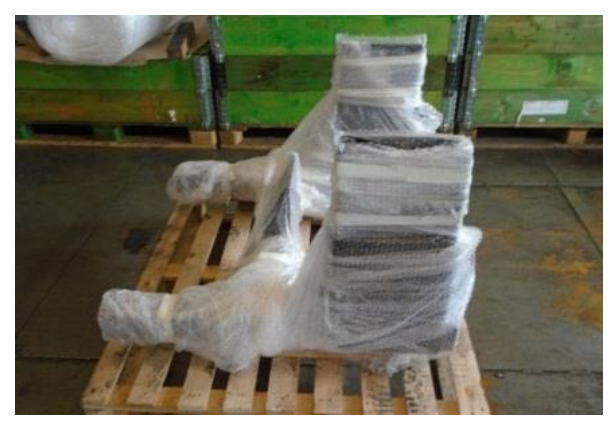

Figure 18. Packaged set for final shipping in the current packaging concept used by the company

Source: The authors.

The occupancy rate per package was increased from $29 \%$ to $86 \%$ with the rearrangement and distribution of the sets in an optimized way inside the "Rack".

The use of Metallic "Rack" provides a reduction of $65 \%$ of the logistics costs to the company, in which it now has the possibility of simultaneously shipping 120 pieces in a single cargo, while in the old model only 28 pieces are shipped, this is due to the impossibility of stacking the packaging (pallets).

Results are significant and shown in Table 1, considering the additional of the reverse logistics (return freight) of the Metal "Racks" that add an additional 50\% of the freight value in the logistics cost, according to the budget made. 
Table 1. Expenses related to Cities of Cruzeiro and São Bernardo do Campo freight to transport item 22B.701.031

\begin{tabular}{llll}
\hline Logistic Costs (Freight US\$) & & \\
\hline Freight & Packing & Partner Company & Market value \\
\hline FV + Toll & Pallet & 261.20 & 322.10 \\
\hline FV + Toll + 50\% RF & "Rack" & 391.80 & 498.15 \\
\hline Freight/Unit Valuation & & \\
\hline $\boldsymbol{C}=\frac{\text { FV }+ \text { T }}{\text { Amount PS }}$ & Piece/Pallet & 9.33 & 11.86 \\
\hline $\boldsymbol{C}=\frac{\text { FV }+ \text { T }+ \text { RF }}{\text { Amount PS }}$ & Piece/”Rack" & 3.26 & 4.15
\end{tabular}

Subtitle: FV = Freight value / T = Toll / RF = Return freight / C = Cost / PS = Piece shipped

Discription: Table showing the logistical cost of freight by the rack occupancy rate.

Source: The authors.

In Table 2, it was defined that the costs of purchasing the packaging currently used to protect and secure a set can be transported and carried without damage. With the use of the new design "Rack" metallic as packaging for parts, it was possible to extinguish the use of all the packages mentioned above, such as: wood, plastic, nylon and adhesive tapes, contributing efficiently to the reduction of costs throughout the process.

To emphasize, there is the possibility of reusing one of the packages, that is, only the wooden pallet could return to the company, however, this does not occur, due to the cost of reverse logistics equivalent to $50 \%$ of freight, this value being higher than acquisition of new pallets, making the return of the packaging completely unfeasible.

Above all, the cost of return shipping, the company that receives the sets $22 \mathrm{~B} .701 .031$ would have to make employees available to select and prepare this return, not to mention that there should be internal and appropriate availability in the client company to pack the other packaging from the product received.

Table 2. Costs of purchasing primary and secondary packaging used to pack, protect and fix the set 22B.701.031

\begin{tabular}{llll}
\hline Primary and Secondary Materials Used in Packaging & \\
\hline & & Cost US\$/Unity & Market Value \\
\hline Material & Quantity & Partner Company & 0.48 \\
\hline Film Stretch 500mm X 25 micra. (10.67Kg) & 12.0 meters & 0.36 & 2.46 \\
\hline Wood Chocks (60X60X600mm) & 02 parts & 1.97 & 0.07 \\
\hline Scotch tape $(50 \mathrm{mmX} 40 \mathrm{~m})$ & 5.0 meters & 0.06 & 0.49 \\
\hline Nylon Strap $(0,7 \mathrm{X} 15 \mathrm{~mm})$ & 9.0 meters & 0.39 & 6.65 \\
\hline Wooden pallet $(1000 X 1000 \mathrm{~mm})$ & 01 part & 5.13 & 10.15
\end{tabular}

Discription: The table showing the cost of purchasing primary and secondary packaging used to embalm, protect and repair 22B.701.031.

Source: The authors.

The return on investment, in the quantitative view, is obtained when the values of the benefits are divided by the amount invested, in order to demonstrate the economic viability, as well as the return time of this project and to approve the making of the product, will be presented by values (Tables 3 and 4). 
Information used as parameters to prove the viability of this project were based on market values, given that the company's cost center provided the information relevant to the values, however, the publication of supporting documents was not authorized.

Table 3. Manufacturing cost of the metallic rack (Unity/Material and Cost)

\begin{tabular}{|c|c|c|c|c|}
\hline \multicolumn{5}{|c|}{ Manufacturing cost of rack } \\
\hline \multirow[b]{2}{*}{ Qty } & \multirow[b]{2}{*}{ Unity } & \multirow[b]{2}{*}{ Material } & \multicolumn{2}{|l|}{ Cost US\$/Unity } \\
\hline & & & Partner Company & Market Value \\
\hline 4 & Parts & Metalon 50x50x2.5 mm & 36.57 & 46.27 \\
\hline 4 & Hours & Labor Boilermaking & 17.24 & 26.12 \\
\hline 11 & Parts & $\begin{array}{l}\text { Nylon/ } \\
\text { Machining }\end{array}$ & 22.39 & 31.34 \\
\hline \multicolumn{3}{|c|}{ Total cost to manufacture per unit } & 7.46 & 103.73 \\
\hline \multicolumn{3}{|c|}{ Total cost to manufacture 40 "Racks" } & 0 & $4,149.25$ \\
\hline
\end{tabular}

Discription: Demonstration of the total manufacturing cost per unit and the total cost to manufacture 40 "racks". Source: The authors.

Table 4. Manufacturing cost of the metallic rack

Valuation of Results in US\$

\begin{tabular}{lllll}
\hline & Partner Company & \multicolumn{3}{l}{ Market Value } \\
\hline & 01 Set & 120 Sets & 01 Set & 120 Sets \\
& 22B.701.031 & 22B.701.031 & 22B.701.031 & 22B.701.031 \\
\hline Logistic costs & 6.06 & 727.61 & 7.71 & 925.07 \\
\hline $\begin{array}{l}\text { Environmental } \\
\text { liability }\end{array}$ & 7.90 & 948.58 & 10.15 & $1,217.91$ \\
\hline Total reduction & $1,676.19$ & & & $2,142.99$ \\
\hline
\end{tabular}

Discription: Table 4 demonstrates the value of savings and cost savings

Source: The authors.

In the financial aspect, the implementation of the project and the making of the metallic "Rack", becomes economically viable, with the recovery of initial investments.

The company has an average demand of 120 pieces/month for the specific set 22B.701.031. The new model allows the packaging of 3 pieces and, therefore, it would be necessary to manufacture 40 "Racks" at a total estimated cost according to the market value of US\$ 4,149.25. However, still as shown in Table 4 above, after the improvement of the improvements in the current model, the monthly reduction would be around R \$2,142.99 and the making of the "Racks" will be amortized over two months.

\section{Conclusion}

Faced with a market saturated with products, in which price, process, quality and technology have gradually become incapable of maintaining an essential differentiation to competitiveness, companies are looking to design for a new element in the composition of their competitive strategy. The direction that the packaging design has been taking places it in a prominent position in this extremely competitive and globalized universe, in which this sector constitutes a segment of great importance in the world industry. 
According to the results obtained by means of the realization of this project, rates of improvement in the productive, logistical and packaging process were raised in a quantitative way. The company that is the focus of the study may increase productivity and consequently its profits, using the metallic "Rack" type packaging, in which by means of the application of the design concept it was possible to improve several aspects that touch the production process, logistics and the product value chain.

It is concluded that the optimization of the physical space during its storage and the best occupation, the elimination of primary and secondary packaging reduce the environmental impact and the occupational health of the worker, with regard to ergonomic aspects by means of RULA.

The reduction of movements involved in the operation provided a significant result to the production chain, customizing transport to the final destination, in addition to reaffirming the quality guarantee, avoiding unnecessary expenses and increasing customer satisfaction.

It was evidenced by the comparison with the current packaging concept, it presents numerous productive, logistical, occupational, environmental and financial advantages, in which the gains with the use of the Metallic "Rack" impacted a significant economy for the company, with the following initiators of performance - KPIs: $82 \%$ reduction in the storage area, $89 \%$ of the times and movements involved in the packaging activity, $65 \%$ of the logistical costs related to transportation, elimination of $100 \%$ of environmental liabilities and an increase in the fee packaging occupancy in the order of $86 \%$ over its entire length.

\section{References}

Abdel-Jaber, M., Beale, R. G., \& Godley, M. H. R. (2006). A theoretical and experimental investigation of pallet rack structures under sway. J. Constr. Steel Res., 62(1), 68-80. Retrieved from https://www.researchgate.net/publication/239351239_A_theoretical_and_experimental_investigation_of_pallet _rack_structures_under_sway

Åhlström, P. (1998). Sequences in the implementation of lean production. European Management Journal, 16(3), 327-334.

ÅhlströM, P., \& Karlsson, C. (2000). Sequences of manufacturing improvement initiatives: the case of delayering. International Journal of Operations \& Production Management, 20(11), 1259-1277. Retrieved from https://www.emerald.com/insight/content/doi/10.1108/01443570010348244/full/html

Associação Brasileira de Embalagens (ABRE). (2021). Destaque inovação sustentabilidade tecnologia. Retrieved June 18, 2020, from http://www.abre.org.br

Baldassino, N., \& Bernuzzi, C. (2000). Analysis and behaviour of steel storage pallet racks, ScienceDirect, Thin-Walled Structures. Thin-Walled Structures, 37(4), 277-304. Retrieved February 18, 2021, from https://www.sciencedirect.com/science/article/abs/pii/S0263823100000215

Baldassino, N., \& Bernuzzi, C. (2000). Analysis and behaviour of steel storage pallet racks. Thin-Walled Struct, 37(4), 277-304. Retrieved from https://www.sciencedirect.com/science/article/pii/S0263823100000215

Barnes, C. G. (1990). Cabbage syndrome: The social construction of dependence. Lewes: Palmer.

Bernuzzi, C., \& Simoncelli, M. (2016). An advanced design procedure for the safe use of steel storage pallet racks in seismic zones. ScienceDiretc Thin-Walled Struct, 109, 73-87. Retrieved from https://www.sciencedirect.com/science/article/pii/S0263823116304876

Bernuzzi, C., Gobetti, A., Gabbianelli, G., \& Simoncelli, M. (2015). Unbraced pallet rack design in accordance with European practice-Part 1: Selection of the method of analysis, ScienceDirect. Thin-Walled Structures, 86, 185-207. Retrieved February 19, 2021, from https://www.sciencedirect.com/science/article/pii/S0263823114002171

Bhamu, J., \& Singh Sangwan, K. (2014). Lean manufacturing: literature review and research issues. Int. J. Oper. Prod. Manag, $\quad 34, \quad 876-940 . \quad$ Retrieved from https://www.researchgate.net/publication/271029631_Lean_manufacturing_Literature_review_and_research_is sues

Bhasin, S., \& Burcher, P. (2006). Lean viewed as a philosophy. J. Manuf. Technol. Manag, 17, 56-72. Retrieved from https://www.emerald.com/insight/content/doi/10.1108/17410380610639506/full/html

Bhattarai, D., \& Mandal, R. A. (2019). Yield regulation and economic analysis of collaborative forest (A study from Lumbini collaborative forest, Rupandehi, Nepal). Discovery, 55(283), 349-360. 
Browning, T., \& Heath, R. (2009). Reconceptualizing the effects of lean on production costs with evidence from the F-22 program. Journal of Operations Management, 27(1), 23-44. Retrieved from https://www.sciencedirect.com/science/article/pii/S0272696308000211

Calver, G. (2009). O que é design de embalagens?. Porto Alegre: Bookman.

Castro, M. A. S. (2005). Prevenção da Poluição Aplicada às Embalagens de uso Industrial: Estudo de Caso. Dissertação (Mestrado) - Escola de Engenharia de São Carlos, Universidade de São Paulo, São Carlos.

Daí, L., Zhao, X., \& Rasmussen, K. J. R. (2018). Flexural behaviour of steel storage rack beam-to-upright bolted connections. Thin-Walled Structures, 124, 202-217. Retrieved from https://www.sciencedirect.com/science/article/abs/pii/S0263823117309977?via\%3Dihub

Dimate, A, E., Rodríguez, D, C., \& Rocha, A. I. (2017). Percepción de desórdenes musculoesqueléticos y aplicación del método RULA en diferentes sectores productivos: una revisión sistemática de la literatura. Revista de la Universidad Industrial de Santander, 49(1), 57-74.

Farias, B. S. S. (2019). Inclusive graphic design for the third age: analysis of the elements iconographic and typographical. Retrieved from http://hdl.handle.net/11449/191372

Furman, J., \& Malysa, T. (2021). The use of lean manufacturing $(\mathrm{Lm})$ tools in the field of production organization in the metallurgical industry. Silesian University of Technology, Katowice, Poland. Scopus. Metalurgija. Retrieved from https://hrcak.srce.hr/index.php?show=clanak\&id_clanak_jezik=372293

Huttmeir, A., Treville, S., Ackere, A., Monnier, L., \& Prenninger, J. (2009). Trading off between heijunka and just-in-sequence. International Journal of Production Economics, 118(2), 501-507.

Liker, J. (2004). The Toyota way: 14 Management Principles from the World's Greatest Manufacturer. New York: McGraw-Hill.

Mantovani, F. P. (2014). Proposta de melhoria do layout de um armazém de vidros automotivos. Trabalho de Graduação em Engenharia Mecânica-UNESP, Faculdade de Engenharia de Guaratinguetá.

Matt, D. T., \& Rauch, E. (2013). Implementation of lean production in small sized enterprises. Procedia Cirp, 12, $420 \mathrm{e} 425$.

Ministry of Labor and Employment. (2018). Regulatory Standard 17- Ergonomics.

Monden, Y. (2015). Sistema Toyota de Produção: uma abordagem integrada ao just in time. Porto Alegre: Bookman, $4^{\mathrm{a}} \mathrm{Ed}$.

Moura, R., \& Banzato, J. M. (1997). Embalagem, Utilização e Conteinerização. São Paulo: IMAM.

Namwongsa, S., et al.. (2018). Avaliação de risco ergonômico de usuários de smartphone usando a ferramenta Rapid Upper Limb Assessment (RULA). PloS One, 13(8), e0203394.

Narayanamurthy, G., Gurumurthy, A., \& Moser, R. (2018). "8A" framework for value stream selection-na empirical case study. Journal of Organizational Change Management, 31(5), 1001-1026.

Nawanir, G., Kong Teong, L., \& Norezam Othman, S. (2013). Impact of lean practices on operations performance and business performance: some evidence from Indonesian manufacturing companies. J. Manuf. Technol. Manag, 24, 1019e1050.

Negrão, C., \& Camargo, E. (2008). Design de Embalagem: do Marketing a Produção. São Paulo: Novatec Editora.

Nordin, N., Deros, B., \& Wahab, D. A. (2010). A survey on lean manufacturing implementation in Malaysian automotive industry. Int. J. Innovat, $1,7$.

Rahani, A. R., \& Al-Ashraf, M. (2012). Production flow analysis through value stream mapping: a lean manufacturing process case study. Procedia Eng., 41, 1727e1734.

Rahman, S., Laosirihongthong, T., \& Sohal, A. S. (2010). Impact of lean strategy on operational performance: a study of Thai manufacturing companies. J. Manuf. Technol. Manag, 21, 839e852.

Rangel, D. A., Freitas, L. M., Assis, O. R., \& Rêgo, T. P. (2012). Increasing production efficiency by the setup time reduction: applying the single-minute exchange of die on a company the beverage industry. $P \& D \mathrm{em}$ Engenharia de Produção, Itajubá, 10(1), 36-49.

Rocha, A., \& Christensen, C. (2008). Marketing: teoria e prática no Brasil (2nd ed.). São Paulo: Atlas. 
Rother, M., \& Shook, J. (2003). Learning to See: Value Stream Mapping to Create Value and Eliminate Muda. Lean Enterprise Institute, Brookline, Ma. EUA.

Santos, J. A. F., \& Oliveira, A. L. (2019). Os benefícios socioambientais das embalagens sustentáveis. Revista Interface Tecnológica, 16(2), 274-286.

Santos, T. M. (2018). A redução do déficit e da desigualdade na cobertura de docentes licenciados na educação básica no Brasil: uma análise do período 2010-2015. 147 f. Dissertação (Mestrado em Administração Pública) Escola de Governo Professor Paulo Neves de Carvalho, Fundação João Pinheiro, Belo Horizonte. Retrieved from http://tede.fjp.mg.gov.br/handle/tede/398

Silva, F, C., Silva, A, L., \& Santos, B. S. (2018). Análise ergonômica em três fases da pintura utilizando o método RULA. Monografia de Especialização. Universidade Tecnológica Federal do Paraná. Londrina/PR.

Sundar, R., Balaji, A. N., \& Kumar, R. M. S. (2014). A review on lean manufacturing implementation techniques. Procedia Eng., 97, 1875e1885.

Tortorella, G. L., Narayanamurthy, G., \& Thurer, M. (2021). Identifying pathways to a high-performing lean automation implementation: An empirical study in the manufacturing industry. International Journal of Production Economics, 231, 2021. $\quad$ Retrieved from https://www.sciencedirect.com/science/article/pii/S0925527320302759

Umar, R, Z, R., Ahmad, N., Halim, I., Lee, P, Y., \& Hamid, M. (2019). Design and Development of an Ergonomic Trolley-Lifter for Sheet Metal Handling Task: A Preliminary Study. Safety and Health at Work, 10(3), 327-335. Retrieved from https://www.sciencedirect.com/science/article/pii/S2093791117304365

Vallejo, V. F., Antony, J., Douglas, J. A., Alexander, P., \& Sony, M. (2020). Development of a roadmap for Lean Six Sigma implementation and sustainability in a Scottish packing company. Emerald insight, Discover Journals, Books \& Case Studies. Retrieved from https://www.emerald.com/insight/content/doi/10.1108/TQM-02-2020-0036/full/html

Womack, J. P., \& Jones, D. T. (1998). A Mentalidade Enxuta nas Empresas: elimine o desperdício e crie riqueza. Rio de Janeiro: Campus.

Womack, J. P., Jones, D. T., \& Ross, D. (2004). A Máquina que Mudou o Mundo: baseado no estudo do Massachusetts Institute of Technology sobre o futuro do automóvel (5th ed.). Rio de Janeiro: Elsevier.

Xu, M., Han, X., Hua, L., \& Zheng, F. (2020). Modeling and methods for gear shaping process and cutting force prediction of variable transmission ratio rack. International Journal of Mechanical Sciences, 171, 2020. Retrieved from https://www.sciencedirect.com/science/article/pii/S0020740319329406

\section{Copyrights}

Copyright for this article is retained by the author(s), with first publication rights granted to the journal.

This is an open-access article distributed under the terms and conditions of the Creative Commons Attribution license (http://creativecommons.org/licenses/by/4.0/). 